\title{
Opening Up Fieldwork with Ethnographic Poetry
}

\author{
Adrie Suzanne Kusserow St. Michael's College
}

Abstract: Four ethnographic poems are used to explore, elucidate and complexify four ethnographic encounters in the field. Each poem is accompanied by a brief explanation as to the ethnographic context in which the poem was written, as well as the reasons why an ethnographic poem was chosen as a tool to illuminate, complexify and do justice to these varying fieldwork experiences. The strengths of ethnographic poetry as a rigorous and subtle tool for cross-cultural understanding is addressed.

Keywords: ethnographic poetry, creative ethnographic writing, anthropological poetry, refugee resettlement, healing and trauma, anthropology of media, American individualism

Resumé : Quatre poèmes ethnographiques servent à explorer, élucider et complexifier quatre rencontres ethnographiques sur le terrain. Chaque poème est accompagné d'une brève description du contexte ethnographique dans lequel il a été écrit, ainsi que des raisons pour lesquelles un poème ethnographique a été choisi comme outil pour éclairer, complexifier et rendre justice à ces différentes expériences de terrain. Les forces de la poésie ethnographique en tant qu'outil rigoureux et subtil pour la compréhension interculturelle sont abordées.

Mots clés : poésie ethnographique, écriture ethnographique créative, poésie anthropologique, réinstallation des réfugiés, guérison et traumatisme, anthropologie des médias, individualisme américain

\section{Introduction}

Ethnographic poetry is part of a growing movement of experimental approaches to ethnography and anthropological inquiry that have gained momentum since the 1990s. As anthropology has increasingly become more open to various literary forms, ethnographic poetry has become a more accepted form of representation. ${ }^{1}$ Aside from journals like Anthropology and Humanism, Anthropoid and others, as well as the Centre for Imaginative Ethnography, which have long supported and highlighted the best in ethnographic poetry, recently, SAPIENS highlighted the amazing work of five ethnographic poets (see Weeber 2020).

Like many anthropologists, I was looking for the most nuanced ways to represent and understand issues encountered in my research in Uganda, South Sudan, Vermont and Bhutan and was particularly drawn to the ways in which form, metaphor, image, rhythm and affect could convey profound subtleties of meaning and bring me to places of fresh insight. During my research, I found that poetry was not something I waited to write until after fieldwork was complete but was helpful in the process of observation itself. Ethnographic poetry could give rise to aesthetic, less linear ways of thinking about the field experience.

Ethnographic poetry is not just about accurately describing an experience but using the insight of its acutely nuanced language and artistic aesthetic to bring a wider array of meaning(s) to these facts than conventional wisdom offered. Far from being a kind of epiphenomenal icing on the cake, poetry encouraged a more rigorous analysis and theoretical understanding of what I observed. In this way, poetry embodied and emboldened my ethnographic research, requiring me to probe behaviours with all my senses. It also gave me the tool of metaphor, which helped me express and pay more deliberate attention to the many ways culture is embodied in the senses of those we study and attempt to represent for others. It was through my poetry that I doggedly 
tried to capture the habitus of working-class parents in Queens, New York, and that brought me to the theories of Bourdieu, which proved essential to understanding my dissertation research (Kusserow 2004). In this way, poetry inspired more enriched and complex theoretical understandings of my collection of data.

Sometimes, the details and necessary descriptive elements of a poem would demand that I go back and observe a ritual or behaviour in a bolder and more focused way than I had before. For example, the poem "Technotropic" (presented below) brought me closer to more refined understandings of the bodily habitus of remote Sherpa women seeing a screen for the first time. The act of coming up with precise metaphors and similes demands an incredibly rigorous attention and honest approach to human behaviour. Vague and generic words do not help anthropologists or their readers crawl into the rich, multi-dimensional places most humans inhabit. Hence, ethnographic poetry is not something that simply reflects an initial ethnographic insight; it is an active ethnographic tool, a deep and refined phenomenological probing, as opposed to a dreamy, distant musing. The tentacles of the ethnographic poem, through image, metaphor, language, form and rhythm, enable me to inch even closer to the complex, subtle experiences I am trying to describe and understand. Like many of my poems, it was the continued reworking of drafts that brought me closer to the ethnographic insights I didn't have going into the poem. Nonetheless, in graduate school, I kept the tool of poetry hidden from my (mostly male, British social anthropology) faculty at Harvard. Back then, I was too afraid to weave poetry into my dissertation, let alone write too poetically for fear that it would represent a divergence, fiction, rather than a much-needed opening and complexification of the monolithic slabs of Truth that have reigned for too long.

The poem "Resignation Syndrome" (below) is based on fieldwork I have done for over ten years now in Vermont, Uganda and South Sudan with South Sudanese refugees known as the Lost Boys and Girls of Sudan. My ethnographic fieldwork has primarily focused on the challenges faced by South Sudanese to resettle in Uganda and the United States, as well as critiqued the western assumptions about what constitutes effective therapy for traumatised refugees. Interviews, participant observation and data collection have been an integral part of many of my applied anthropology projects in South Sudan and Uganda. I worked with the Lost Boys of Sudan based in Vermont to help co-found the South Sudan-based NGO Africa Education and Leadership Initiative: Bridging Gender Gaps Through Education (AfricaELI; see http://AfricaELI.org). Thanks to a World
Bank grant, fieldwork also consisted of helping build and run a secondary boarding school for refugee girls from all over South Sudan based in Yei, South Sudan. After war displaced girls from this boarding school, subsequent interviews with South Sudanese girls attending boarding schools in Uganda also led to the design of programs run by AfricaELI to assess and support the challenges of refugee secondary education among girls deemed traumatized by largely western-trained social workers in Kampala, Uganda.

The first time I encountered resignation syndrome was with a South Sudanese woman I knew quite well in the area where I live (Burlington, Vermont). After her husband found her in a coma on the couch in their apartment, she was admitted to the hospital for observation, and yet her vital signs remained normal. I had heard of the high rates of resignation syndrome occurring mostly in Sweden (Uppgivenhettsyndrome) among primarily Russian youth who had been denied asylum. I never thought I would encounter it among the South Sudanese.

What was most interesting to me was how we were told to pretend things were normal and speak to her as if she were awake while she was in a coma. I was also interested in the social worker's response to her healing treatment once she got home, which was to get out of the house and avoid being too isolated, even though what most soothed her was watching soap operas on television. I knew I had to write about this through ethnographic poetry because I needed poetic language and rhythm to juxtapose the strangely surreal and haunting aspects of what was going on in her home at the time of her coma and recovery. I also needed a format that would allow me to explore and condense all of the intertwined and interdependent realities occurring simultaneously (motherhood, war, trauma, healing, social workers, asylum seekers, television). Much of my fieldwork involved negotiating with local Vermont social workers who advocated not overeating, watching less television and getting out more as part of the healing process from resignation syndrome. I found that after countless hours of sitting and watching television with this Sudanese mother, and talking to her about what she loved about television, I had to confront my own bias of seeing television as bad, as denial, as brainwashing, and entertain the idea that it might be therapeutically effective for her insofar as it enabled her to let certain memories float through rather than possess her.

\section{Resignation Syndrome}

A dissociative syndrome that brings on a catatonic state that can last for years, found among young refugees 
after learning they have not been granted asylum. While mostly in Sweden, cases are being found among children in Australian asylum detention prisons in Nauru.

Who knew after hearing her asylum was denied, Ayen, too, would lie on her couch in a coma, catatonic, her toddler bouncing her Barbie down the length of her stiff long legs, a case worker awkwardly pumping her breastmilk for her newborn, its plunging nasal wheeze rising and falling.

Who knew the psyche could be so clever! Playing possum

til danger passes. Who knew

waves of migration worked through bodies

with such cunning, laying waste

to beds of snow whites, feeding tubes snaking

through their bedsheets. Who knew,

sometimes when war rolls over, like a grumpy lover, only the top of the psyche sticks to its back, the unconscious left mute and leaking behind.

Her vitals normal, nothing to do but wait, the head doctors say, talk to her of happy things, Abuk's new tooth, Deng's new job, push her wheelchair to the dinner table, close to the steaming white rice, cup her hand and help her draw a picture of the sun or a Dinka cow.

Finally Ayen rises to the surface, mumbling, "it felt like drowning, deep underwater"

Whether she floated up

effortlessly upon hearing the theme song of her favor-

ite soap, One Life to Live, or clawed her way onto the rescue limb of the nurse's chipper blood pressure read, she does not remember.

Whether consciousness can be baited

and lured back up

once it's sunk like an anchor,

we don't really know.

Hard to say just what entices, say the white coats, the courage to swim up,

found mostly in a mother's voice, tones of hope transferred to the child.

Now upright, awake, her dizziness gone, the social workers deem Ayen "grounded" she is good to go, the promise of America settled like sediment to the bottom of her cells.

At home, each day she follows

her caseworker's advice -

forcing herself to rise from the pull of her daytime shows, get out of the house, do the shopping, into the malls where she felt lonely as a ghost, where humans glistened with devices that deflect and protect, and she barely brushed up against casual glances, nothing too human, just the low magnetic pull of the bored cashier or the Starbucks barista.

Later, when hunger for her mother's fish kajaik, makes her salivate, and she follows the social worker's rules

not to gain too much weight, from the Comcast menu she eats and eats, lifts the remote worn smooth as a stone from rivers of hands, bathes in the giant technicolor TV spread like a blooming aquarium across their wall, displacing somber frames of Dinka army leaders in cowboy hats who just betrayed her anyway.

Is it any wonder she likes sinking into their giant Salvation Army couch, Abuk's sleeping face lighting up like a billboard when commercials flash, Ayen resting deep in the underworld of One Life to Live, its vast, quiet mansions, clinking ice, swish of gowns.

the sounds of war floating in her brain, muted, the screams compressed now into a gentle distant moaning, like the songs of whales, slowly sliding through her mind, and finally far beyond.

As an anthropologist interested in media, I have done fieldwork in Ladakh, northern India, Nepal and Bhutan, working with rural Buddhist youth recently exposed to the internet, social media and television. I have done most of my fieldwork during applied fieldwork trips to Bhutan, where I work with rural youth in the Media Nomads Project I helped develop with the Bhutan Centre for Media and Democracy. Fieldwork involved running youth workshops on critiquing western media for youth who had never been exposed to social media or the internet, as well as conducting focus groups on adjusting to life with social media.

While this trip to Darjeeling was not ostensibly about media literacy, it did involve showing residents in very remote villages a film (in which actors mimicked a human trafficking scenario) on a laptop we lugged around through remote Himalayan villages on the Indo-Nepal border. I was really struck by the way in which these residents responded to seeing a film on a screen for the first time, as well as the Sherpas' precious 
and guarded time in their tents with their newly charged iPhone at the end of the day. The contrast between the profound interest and fascination with screens and my own doubts as to how screens were influencing human consciousness was striking.

Since I had brought my American teenage screensavvy children into the field with me on this trip, I was able to study the differences between bodily and facial affect when watching something. I turned to ethnographic poetry because I needed poetic language to encompass the subtleties of these differences, as well as metaphors and images that would capture the ways in which consciousness was so immediately entranced by screens in this day of portable technology. I also felt a poem could better accommodate a self-reflective section on the anthropologist as mother, who learns about her own culture by watching her children consume technology and jumps forward in time in her imagination, exploring how this technology would be conceptualised by future humans. This kind of imaginative temporal shift, as well as the mother's desire to try and see the influence of technology on human consciousness in an ultimately more liberating and less pessimistic vein, is something I felt only an ethnographic poem would allow me to do.

\section{Technotropic}

I.

Darjeeling District Nepal/India Border

For three days we have trekked

to this tiny village on a mountain ledge, devices zip-locked into padded black bags, camera antennae tucked into themselves humbly, so as not to call attention.

We are here to spread a kind of gospel of fear, warning girls that traffickers lurk everywhere. Under the rickety bamboo shack we begin with a cautionary film.

Women strain toward the screen, pushing each other aside,

swatting at the incense that winds like a ghost through their vision, black eyes milking the tragic plot as the villain is caught, their faces bruising, shadowing,

lighting and flowering

in giant swells of emotion

that leave not one cell behind.

II.

Back at camp, Sherpas sport solar chargers on their backs,

slick panels gleaming iridescent as beetles

in the Himalayan sun.

As they cook, they rotate inch by inch,

capturing the sun's last meek rays,

enough to resurrect their dead phones for later.
Well into the night, you see their North Face tents bulging at the seams, lit with a desperate, restless light, virtual Sherpas scaling the web, their giant longing for the West just barely trapped, like hundreds of captured moons.

\section{III.}

In Darjeeling, I find my daughter, my son, tucked inside the wifi cafe both of them laptop glued. Unlike the Nepalis, not even a ripple of affect passes through their faces, and what bits rise to the surface so tiny,

mere minnows that flit away, into the cool amniotic blue.

How soon will it take, after they greet me, their eyes dutifully fixed on mine, while underneath their cells furtively gather, at first just a few,

then thousands stealthily migrating back toward their screens, and though they answer my questions, little by little their tectonic plates shift, faces masking their divided loyalty, with puppets I'm suspicious of, but can't readily accuse.

IV.

In the mountains, I try and coax the kids out, but once the sun sinks, they zip themselves in, deep screening, recharging, digging like moles through the web, leaving their tracks on browsers I'm tempted to check the next day, I squish down into my sleeping bag, vowing to emerge with more hope for this techno evolution.

Perhaps someday when we are fully wired and the internet juices and sluices our veins, there will be a quaint name for the days when the present moment was so narrowly perceived, (limited to the body's five clumsy senses, a cluster of nearby humans, a local geographic space). We will look back bewildered at the grief that overcame elders when they felt their young's attention shift allegiance, laugh at their drugs meant to trap their focus, analyze their apocalyptic writings, their grieving songs played in the key of loss, mourning the day they thought the psyche had fled the present moment and split in two.

Forgiving them, because they could not have known that consciousness was doing what it was always meant to do, a jeweled net refracting, 
reflecting the infinite

in its every nodule, no single source, no single present moment, only a kind of blessed, welcomed impermanence everywhere rising and falling.

I don't always bring my children into the field with me, but last summer I was in Malmo, Sweden, interviewing refugees while my son went skateboarding with his American friends. Fresh from teaching a class on Pierre Bourdieu, I was immediately struck by the bodily habitus of these upper-middle-class American boys compared to the refugees I encountered in Malmo. I watched him and his friends move through a foreign space, and the contrast between the two cultures was quite pronounced. I doubt I would have been as aware of the bodily inhabitancies of hesitance, wariness and caution with many of the refugees I encountered were it not for the contrast that my son provided in his cocky and confident ownership of the streets. I was reminded of the contrast and strikingly different bodily habit of children in wealthy parts of Manhattan and poor parts of Queens, New York. I needed a form of writing that could accommodate the fluid, poetic, confident, effortless ease with which they moved through the city.

Once I saw the boys through the eyes of the refugees, and realised how ludicrous the boys' antics looked to them, I no longer felt proud but rather embarrassed by their level of confidence. I thought an ethnographic prose poem would help me poetically explore their upper-middle-class white habitus as it manifested itself in skateboarding, as well as make the familiar (my son's skateboarding) strange, insofar as it allowed me to fully enter the poetics of his movement on the streets. I felt the rhythm I needed to convey the kind of habitus these American boys commanded as they swept through Malmo could only be captured through a poem. I also wanted a poem that could hint at (instead of baldly state) my subtle critique of American socialisation practices that live on through the bodies of boys as they explore (and in some ways dominate and own) the world around them.

\section{Skateboarding, Malmo, Sweden}

More hijab'd refugees than blondes, blue collared Malmo sprawls, grey industrial bleak, shipyards hunkered down, sheepish against the North Sea's daily whippings. My son dodges my lectures on all the grim global forces at play, the capsized dinghies, the Syrians and Iraqis clawing to shore. He and his skateboard crew, oblivious, just want to cruise, look for ledges, lines, angles, jumps, and fly as one, scraping the streets into joyous rage, a gritty, reckless surfing, a brotherhood, an ownership, a cocky love of the carve, tilt and lean. Impossible not to envy their graceful streetsurf, afraid of nothing it seems, not the cracks, benches, stairs, police. In quick high fives, they slap their tags on stop signs, crosswalks, mailboxes, bits of anarchy spitting sparks in their wake, neon grins stoked with a confidence only American preschools breed.

Downtown, I interview a Syrian girl in black hijab, weighted with grocery bags, her tiny brother with his water-logged black eyes hiding behind her legs. My son's crew races by, metallic thunder, steel vibrations crashing in their wake. I wait for her awe to ignite, seduced by their energy's defiant magnetic pull. But no part of her is enticed by this brilliant tornado, this roving cocky brotherhood - no envy, no anger, no awe, her face deadpan with settled fate, that some fly and others wait. All day they scrape, jump and slide off rails, ramps, stairs, then disperse, flying like hawks, scanning the city for the choicest concrete prey. Each fountain, statue, stone bench or table an invitation, an appropriation, a democracy, a chance to play. What do you think of this? I say. She looks down, clucks a tsk tsk, in cities, she says, best to be wadie (humble) around such shapes.

Late that night, dressed in black, spackled in spray paint, they gather, a murder of gangly crows. In their notebooks, they mimic Basquiat, Banksy and urban hardcore, but as free as they are they want more and more. So they sneak out to slam, bomb and slash tags.

Later a phone call, the Swedish police, my son arrested - chased, pinned, pepper sprayed, stripped, he sits blind in a cell for hours before released. The next morning I scan his mood. Is it any wonder he rises nonchalantly, the mild beatings miniscule molecules swallowed by his feisty cultural DNA, police humiliations eaten up by the great American self esteem machine. Remember Circle Time, each child's story painstakingly worshipped and adored, remember the Sky's the Limit, etched on his bedroom door. Is it any wonder the next morning, he is giggling and joking, rough housing like puppies, tweaking his videos, reworking a trick, rejoining his radiant crew as they scarf down cereal and begin another day as kings.

On the flight home, we look down on grim Malmo with its tight-lipped streets, quiet and prostrate, how it seems to just accept a kind of bifurcated fate - while refugees lock their doors and sleep, American boys awake, spilling into the concrete, as if the streets were begging them, come American boys, unfold, create, do with us what you must to be great.

The following poem is based on fieldwork I did with Bhutanese elderly refugees in Burlington, Vermont, for 
five years. Thanks to my Nepali translator, Neera BK, and the superb ethnographic research by Liana Chase (2011) on Bhutanese refugee resettlement in Vermont, I was able to conduct an ethnographic study for the Community Health Center in Burlington, Vermont, on the well-being of Bhutanese elderly refugees in Vermont. Most of my data was collected through semi-structured interviews with Bhutanese individuals and focus groups, as well as participant observation in the Bhutanese Elderly Lunch Program sponsored by Mercy Connections and the Vermont Refugee Resettlement Program.

Ethnographic poetry sometimes acts as a kind of magnifying glass, allowing the anthropologist to take one small moment, like this one on a plane from Delhi to New York, and augment its details using the tools of metaphor, simile, image and rhythm to really explore the subtlety and complexity of the moment in which an elderly Bhutanese refugee man struggled with capitalism's airplane culture and its assumed rituals around affect and screen use. As an anthropologist interested in the spread of global media to remote populations that have not already been exposed to the internet, I have been extremely interested in the kind of emotional life such screens encourage, promote, discourage. An ethnographic poem also allowed me to get even closer to and intensely focus on the subtle intricacies of body language and non-verbal behaviour that were evocative of larger socio-cultural and globalising forces at play.

\section{Refugee Encounters with Feelings of a Capitalist Kind}

Across the aisle sits Bimal, the elderly Bhutanese man, who sold me tea from his shack in a soggy camp where work is rare, people too poor for TV or iPhones, everyone sticky with desire for face to face interaction.

Each day he clambered through thickets of greetings,

jungles of curious tendrils, viscous eager stares insisting upon a response.

Especially during the monsoon, when drama was high, feelings hung about for months, ripening, fermenting, refusing to dry.

Now on this sterile, silent flight, bulleting toward New York,

he fidgets with the remote.

It's agony to watch,

like a lamb at a cold plastic teat, clumsy, awkwardly fumbling.

I watch him rise, drag his smile through the aisles of passengers

docked at their stations, silently feeding,

searching for ones between movies

more apt to engage because

all he needs is one kind exchange

to take back to his seat and feast on.

He hasn't learned how to

point the remote like a wand until colors explode, surfing the channels of $\mathrm{HBO}$, Netflix, Amazon,

deciding how he wants to feel

from menus of shows

with limited liability feelings

that won't drench the psyche for too long, interrupt the work day or dampen a vacation.

Disposable feelings that can be taken off, stuffed like a kerchief into a sleeve

once the credits roll and the plane begins its bumpy

descent.

When the beverage cart reaches him,

he milks the stewardess' sweet but weak emotional tug for all it's worth, her smile no stronger

than a twice used teabag,

her cheery banter, chirping high above him, noncommittal, casual, as she cracks the sodas open, shovels in ice, pours, repeats,

her kindness glistening

on her motions without slowing them down.

I watch him fumble, nervous,

already he knows not to take too long,

or let his coil of loneliness unfurl.

I worry the soda will spill,

spread like shame across his lap,

but how quickly Coke accommodates

her frantic pace,

seeping into the hollows of the ice cube skulls,

and when there's no more room, or time,

and the plane begins its measured descent,

how efficiently the foam rises, bubbles, breaks

as it lands on his tray, the mist barely gracing his chin.

Adrie Suzanne Kusserow, Department of Sociology

and Anthropology, St. Michael's College, Colchester,

Vermont, United States. Email: akusserow@smcvt.

edu.

\section{Note}

1 See, for instance, Cahnmann-Taylor (2018); Daniel and Peck (1996); Diamond (1986); Gottlieb (2017); Maynard (2001); Maynard and Cahnmann-Taylor (2010); Pandian and McLean (2017); Tarn (2007); Tedlock and Mannheim (1995). Ethnographic poets include but are by no means limited to Jess Auerbach (2020); Ivan Brady (1991, 2003); Melissa Cahnmann-Taylor (2008b; 2016; 2018; see also Cahnmann 2006); Stanley Diamond (1986); Paul Friedrich (1996, 2006); Dell Hymes (1993a, 1993b, 2003); Michael Jackson (1989); Adrie Kusserow (2002, 2007); Kent Maynard (2002); Renato 
Rosaldo (2006, 2013, 2019); Nomi Stone (2008, 2019); Nathaniel Tarn (1986, 2002, 2007); Tarn and Martin Prechtel (1997); Leah Zani (2019); and Ather Zia (2001, 2014).

\section{References}

Auerbach, Jess. 2020. From Water to Wine: Becoming Middle Class in Angola. Toronto: University of Toronto Press.

Brady, Ivan.1991. Anthropological Poetics. New York: Rowman and Littlefield.

— 2003. The Time at Darwin's Reef: Poetic Explorations in Anthropology and History. Lanham, MD: AltaMira.

Cahnmann, Melisa. 2008a. "Ghetto Teachers' Apology." Anthropology and Humanism 31 (1): 83. https://doi. org/10.1525/anhu.2006.31.1.83a.

Cahnmann-Taylor. 2016. Imperfect Tense. San Pedro, CA: Whitepoint Press.

Cahnmann-Taylor, Melisa. 2008b. "Arts-Based Inquiry: Histories and New Directions." In Arts-Based Research in Education: Foundations for Practice, ed. Melisa Cahnmann-Taylor and Richard Siegesmund, 3-15. London: Routledge.

— . 2018. "Introducing the 2017 Prizes: A Good Year for Ethnographic Poetry." Anthropology and Humanism 43 (1): 126-134. https://doi.org/10.1111/anhu.12199.

Chase, Liana. 2011. Coping, Healing and Resilience: A Case Study of Bhutanese Refugees in Vermont. BA thesis, Dartmouth College.

Daniel, E. Valentine, and Jeffrey M. Peck, eds. 1996. Culture/ Contexture: Explorations in Anthropology and Literary Studies. Berkeley: University of California Press.

Diamond, Stanley. 1986. Poets/Anthropologists, Anthropologists/Poets. Special issue of Dialectical Anthropology 11 (24).

Friedrich, Paul. 1996. "The Culture in Poetry and the Poetry in Culture.” In Culture/Contexture: Explorations in Anthropology and Literary Studies, edited by E. Valentine Daniel and Jeffrey M. Peck, 37-57. Berkeley: University of California Press.

_ 2006. From Root to Flower. N.p.: Virtual Artists Cooperative.

Gottlieb, Alma. 2017 "Poems about Refugees: An Interview with Adrie Kusserow.” 19 March. Accessed 23 July 2020. http://almagottlieb.com/2017/03/poems-about-refugees/.

Hymes, Dell. 1993a. "Fivefold Fanfare for Coyote." In A Coyote Reader, edited by William Bright, 50-55. Berkeley: University of California Press.

—. 1993b. "Spearfish Sequence." In A Coyote Reader, edited by William Bright, 178-179. Berkeley: University of California Press.

- 2003. Now I Know Only So Far: Essays in Ethnopoetics. Lincoln: University of Nebraska Press.

Jackson, Michael. 1989. Duty Free: Selected Poems, 1965-1988. Dunedin, NZ: J. McIndoe.
Kusserow, Adrie. 2002. Hunting Down the Monk. American Poets Continuum Series. Rochester, NY: Boa Editions.

- 2004. American Individualisms: Child Rearing and Social Class in Three Neighborhoods. New York: Palgrave Macmillan.

—. 2007. "Skull Trees." In The Best American Poetry, edited by Charles Wright and David Lehman, 66-67. New York: Scribner.

Maynard, Kent. 2001. Sunk like God behind the House. Kent, $\mathrm{OH}$ : Kent State University Press.

—. 2002. "An 'Imagination of Order': The Suspicion of Structure in Anthropology and Poetry." Antioch Review 60 (2): 220-243. https://doi.org/10.2307/4614312.

Maynard, Kent, and Melisa Cahnmann-Taylor. 2010. "Anthropology at the Edge of Words: Where Poetry and Ethnography Meet." Anthropology and Humanism 35 (1): 12-19. https://doi.org/10.1111/j.1548-1409.2010.01049.x.

Pandian, Anand, and Stuart McLean, eds. 2017. Crumpled Paper Boat: Experiments in Ethnographic Writing. Durham, NC: Duke University Press.

Rosaldo, Renato. 2006. "To Machu Picchu." Anthropology and Humanism 31 (1): 84-85. https://doi.org/10.1525/ anhu.2006.31.1.84.

—. 2013. The Day of Shelly's Death. Durham, NC: Duke University Press.

- 2019. The Chasers. Durham, NC: Duke University Press.

Stone, Nomi. 2008. Stranger's Notebook: Poems. Evanston, IL: TriQuarterly Books.

- 2019. Kill Class: Poems. Dorset, VT: Tupelo Press.

Tarn, Nathaniel. 1986. Palenque. Meriden, CT: Oasis/ Shearsman Press.

—. 2002. Selected Poems: 1950-2000. Middletown, CT: Wesleyan University Press.

—. 2007. The Embattled Lyric: Essays and Conversations in Poetics and Anthropology. Stanford, CA: Stanford University Press.

Tarn, Nathaniel, and Martin Prechtel. 1997. Scandals in the House of Birds: Shamans and Priests on Lake Atitlan. New York: Marsilio.

Tedlock, Dennis, and Bruce Mannheim, eds.1995. The Dialogic Emergence of Culture. Urbana, IL: University of Illinois Press.

Weeber, Christine. 2020. "Why Poetry + Anthropology?" Sapiens, 20 March. https://www.sapiens.org/language/ anthropological-poems/ (accessed 23 July 2020).

Zani, Leah. 2019. Bomb Children: Life in the Former Battlefields of Laos. Durham, NC: Duke University Press.

Zia, Ather. 2001. The Frame: An Anthology of Poems. Srinagar, Kashmir: J7K Cultural Academy of Arts and Languages.

—. 2014. "The Ex-Fighter Returns." Anthropology and Humanism 39 (1): 94-95. 